\title{
EDITORIAL: THE MUSICNESS OF MUSIC
}

\author{
Christopher Fox
}

'A melody is a melody is a melody is a melody, you see. That's the problem, a melody is a melody, it's not a photograph, it's not this, it's not that, it's a melody.' Not Gertrude Stein but Morton Feldman, in conversation in 1985 with Francesco Pellizzi, ${ }^{1}$ obliquely questioning the nature of musical subject matter, the issue that haunted him throughout his creative career. For Feldman the irreducible identity of a melody was the antithesis of the imageless music that he wanted to create, particularly in the works of his final decade. Instead, those works are a celebration of the identity of the instruments for which they are written. If melody is no longer a subject in a piece such as Piano, Violin, Viola, Cello, then the nature of those four instruments, and how they might sound together, most certainly is. Perhaps this explains why these late Feldman works are so popular: they sound like music but don't require the sequential (and consequential) listening necessary in music where melody is the subject.

The music of the two composers whose work is considered in the first five articles of this issue of TEMPO also raises questions about what makes music so musicish. As the title of Tom Crathorne's article about Philip Venables' 4.48 Psychosis - 'Just a Word on a Stave and There Is the Opera' - suggests, in turning Sarah Kane's play into a piece of music-theatre Venables' work has essentially been to reveal the music implicit in Kane's text. The resulting work is, as a result, intensely theatrical, and even in its most 'musical' moment, 'Clare's Song', in Scene 11, Venables' version of 4.48 Psychosis references a scene in Kane's play Cleansed.

Thomas Adès, by contrast, is a composer whose work thrives on its very evident musicness. To celebrate Adès's fiftieth birthday Edward Venn has drawn together a symposium on different aspects of his work, and a recurrent theme throughout all four of the articles that make up this symposium is Adès's skill in deploying compositional devices that can be quite readily heard. Whether they are the notquite horn calls of the Piano Quintet, the sonata form of the Concerto for Piano and Orchestra or the white-note passacaglia of Dawn, these are devices familiar from a host of previous musical works, devices that Adès is using not only because he wants us to hear them, but also because he wants us to know that he knows that we can hear them. As listeners we are caught up in a web of knowing.

This has something to do with Adès's considerable success. As Edward Venn points out in his introduction to the symposium, the concerts that have marked Adès's anniversary have rarely been retrospective, because so much of his music has established itself as part of the repertoire of mainstream classical music-making. As the Amazon

\footnotetext{
1 'Morton Feldman: A Conversation with Francesco Pellizzi', in Vertical Thoughts: Morton Feldman and the Visual Arts, ed. Seán Kisane (Dublin: Irish Museum of Modern Art, 2010), p. 290.
} 
algorithm might say, if you enjoy classical and Romantic music, you will probably enjoy Adès's music; it will remind you of things you already know, but will remind you with sufficient subtlety to afford you the additional pleasure of feeling that you are discovering artfully hidden treasures.

It may be, however, that the success of this most musicish music is difficult to sustain in an era when audiences are increasingly diverse in their backgrounds. How does Adès's music sound to listeners who don't hear its artfulness? Is a Feldmanesque iconoclasm more suitable in a world where, because we all know far more music than people have probably ever known, it becomes less and less likely that there will be a commonality in people's musical experience? I don't know, so this issue also includes two manifestos, both provocative in their different ways, one proposing ways of curating our relationship with existing music, the other advocating a music of 'transgression' and 'sensation'.

It is with great sadness that we note the passing of three major figures within British new music, the composers Simon Bainbridge (19522021) and Anthony Payne (1936-2021) and the soprano Jane Manning (1938-2021).

Anthony Payne (1936-2021) had a long career as both a writer and as a composer. As a critic for Music and Musicians he reviewed a Park Lane Group concert in which a young Jane Manning made her London debut, and he observed that her performance of Messiaen's Poèmes pour Mi sounded 'strained'. ${ }^{2}$ She married him two years later. Payne's compositional career was slow to start, and he was already in his thirties when the Phoenix Mass, for choir and brass sextet, was premiered. It remains one of his most striking works, balancing sustained, lyrical writing for the singers with more astringent, dissonant music for the brass, and a fine recording from 1977 opens Payne's NMC portrait album, Phoenix Mass (which also includes two other works from the 1970s, Paean and The World's Winter, and the Horn Trio, completed in 2006).

In the 1980s the lyrical side of Anthony Payne's musical personality became more evident in a series of chamber and orchestral works of which Time's Arrow (1989-90) is perhaps the best known. Payne's original compositions were overshadowed in the mid-1990s by his gradual realisation of a complete score from Edward Elgar's sketches for a third symphony. Symphony No. 3 (Elgar/Payne) was premiered in 1998 to considerable critical acclaim and has gone on to receive many performances and six recordings. Payne was also a devoted husband, supporting Jane Manning throughout her career and helping to manage the ensemble that she created, Jane's Minstrels. He died on 30 April 2021, only a month after his wife's death.

Simon Bainbridge first came to prominence in his late teens with the Aldeburgh premiere of his ensemble piece Spirogyra (1970), and a series of glitteringly attractive works followed. People of the Dawn (1975) was written for Jane Manning and the Matrix ensemble, and in the 1976 oboe and piano duo Music for Mel and Nora he fused the rhythmic energy of 70 s American minimalism with the timbral and harmonic precision of Berio; later it would form the basis of his Concertante in moto perpetuo (1982).

\footnotetext{
${ }^{2}$ George Nicholson, 'Jane Manning', Composer, no.78, Spring (1983), p. 18.
} 
Later in the 1980s a more restrained manner would come to characterise his mature works, in which taut counterpoints are spun out of carefully voiced harmonic constellations. The best known of these works is undoubtedly his setting of four poems by Primo Levi, Ad Ora Incerta (1994), for mezzo-soprano, bassoon and orchestra, and in 1997 Simon Bainbridge was awarded the University of Louisville Grawemeyer Prize for this work. Bainbridge was also a gifted conductor and a much sought-after teacher; he was Head of Composition at the Royal Academy of Music in London from 1999 until 2007.

Later in this issue we pay an extended tribute to Jane Manning; it's a sort of posthumous profile and consequently the profile feature that usually concludes each issue of TEMPO has been omitted. It seems appropriate to focus at greater length on Jane Manning because she had such an extraordinarily decisive role in changing new music in Britain, particularly in the first three decades of her career, from the 1960 s to the 1980s. She was a member of that generation of musicians whose work as soloists and in ensembles like the London Sinfonietta and the Fires of London transformed performance practice. For them the technical challenges that would have had older musicians complaining about unperformability were no more than a gateway into a world of new expressive possibilities.

Like all virtuoso soloists, Jane Manning could also make any piece of music sound exciting, sometimes to the extent that the most memorable features of a new score were her work rather than the composer's. But among the hundreds of new works that she commissioned there are many that have stood the test of time, so many that it would be invidious to single any out here. Her musical legacy also includes many superb recordings and, testament to her commitment to the work of the singers who might follow her, a series of revelatory publications: Voicing Pierrot, in which she goes to the heart of a work she made her own, Schoenberg's Pierrot lunaire, and four volumes for Oxford University Press in which she introduces new vocal repertoire. Her joy, so evident in her every encounter with music and the people who make and listen to it, was a marvel to behold. 